\title{
OPTIMALISASI PEMBANGUNAN EKONOMI NASIONAL MELALUI OTONOMI DESA
}

\author{
Ardhiwinda Kusumaputra \\ Fakultas Hukum Universitas Brawijaya \\ e-mail: ardhiputra82@gmail.com
}

\begin{abstract}
ABSTRAK
Desa merupakan bagian tak terpisahkan dari Negara Kesatuan Republik Indonesia. Eksistensi pemerintahan desa ini diakui dan dihormati secara konstitusional dalam Pasal 18B ayat (2) Undang-Undang Dasar Negara Republik Indonesia Tahun 1945. Desa mempunyai otonomi dengan karakteristik tersendiri. Melalui otonomi ini desa dapat mengatur dan mengurus urusan pemerintahan desanya. Pada dasarnya otonomi desa dapat menjadi penggerak atau poros dalam pembangunan ekonomi nasional. Potensi desa yang begitu besar dapat dimanfaatkan dalam meningkatkan ekonomi nasional. Menjadi suatu permasalahan tentang bagaimana integrasi antara hukum modern negara dengan hukum yang hidup di desa, dalam kaitannya dengan pembangunan ekonomi nasional, dan bagaimana cara mengoptimalkan pembangunan ekonomi nasional melalui otonomi desa, serta Melakukan integrasi hukum ini perlu dilakukan melalui proses pembentukan hukum modern negara (peraturan perundang-undangan). Mendasarkan pada tiga pijakan penting dalam penyusunannya. Selain itu perlu juga untuk merefleksi kembali pemahaman tentang Pancasila. Optimalisasi pembangunan ekonomi berdasarkan otonomi desa, dilakukan melalui pemberdayaan dan pembenahan masyarakat, serta melakukan penataan pembentukan dan pelaksanaan Badan Usaha Milik Desa.
\end{abstract}

Kata Kunci: optimalisasi, pembangunan ekonomi nasional, otonomi desa.

\begin{abstract}
Village is Republic of Indonesia integral part. The existence of the village administration is constitutionally recognized and respected in Article 18B (2) of the Republic Indonesia Constitution 1945. The village has autonomy with its own characteristics. Through this autonomy village will be able to regulate and administer the village government. Basically village autonomy can play an important role in the development of national economic. The potential of village can be used in improving the national economy. There came the problems about how is the integration between modern legal state law with village law related to the national economic development, and how to optimize the national economic development through village autonomy. This kind of law integration needs to be done through the process of establishing a modern state of law (legislation). Based on three important step in their preparation. It is also necessary to reflect the understanding of Pancasila. Optimization of economic development based on the village autonomy, can be conducted through the empowerment and improvement of society, and the arrangement of the formation and implementation of village-owned enterprises.
\end{abstract}

Keywords: optimization, national economic development, village autonomy.

\section{PENDAHULUAN}

Desa merupakan satuan pemerintahan yang diakui, dihormati dan dilindungi dalam kerangka Negara Kesatuan Republik Indonesia. Secara konstitusional, eksistensi desa ini diakomodir berdasarkan Pasal 18B Undang-Undang Dasar Negara Republik Indonesia Tahun 1945 (selanjutnya disingkat UUD NRI 1945). Adanya ketentuan dalam konstitusi, memberikan konsekuensi bahwa desa merupakan bagian penting negara. Hal ini mengingat pengertian dasar tentang konstitusi oleh K.C. Wheare, ${ }^{1}$ menyatakan bahwa constitution is used to describe the whole system of government of a country.

${ }^{1}$ K.C. Wheare, Modern Constitution, Oxford University Press, London, 1966, h. 1. 
Begitu pula C.F. Strong, ${ }^{2}$ menyatakan bahwa a constitution may be said to be a collection of principles according to which the powers of the government, the right of the governed, and the relations between the two are adjusted. Pengertian tersebut mengantarkan pada suatu pemahaman bahwa desa merupakan bagian dari sistem pemerintahan yang juga mempunyai kekuasaan yang dibatasi oleh peraturan perundang-undangan.

Sebagai bentuk peraturan turunan dari UUD NRI 1945, maka dibentuklah Undang-Undang Nomor 6 Tahun 2014 tentang Desa (selanjutnya disingkat UU No. 6 Tahun 2014). Munculnya UU No. 6 Tahun 2014 sebagai salah satu langkah pemerintah untuk semakin memaksimalnya peran desa melalui otonomi desa.

Pengertian tentang desa sebagaimana dimaksud pada Pasal 1 angka 1 UU No. 6 Tahun 2014 adalah Desa adalah desa dan desa adat atau yang disebut dengan nama lain, selanjutnya disebut Desa, adalah kesatuan masyarakat hukum yang memiliki batas wilayah yang berwenang untuk mengatur dan mengurus urusan pemerintahan, kepentingan masyarakat setempat berdasarkan prakarsa masyarakat, hak asal usul, dan/atau hak tradisional yang diakui dan dihormati dalam sistem pemerintahan Negara Kesatuan Republik Indonesia (yang selanjutnya disingkat NKRI).

Berdasarkan pengertian tersebut dapat dipahami bahwa melalui UU No. 6 Tahun 2014, pemerintah berusaha untuk menyeragamkan istilah desa maupun desa adat dengan sebutan desa. Ketika menyebutkan istilah desa, berarti mencakup desa (konvensional) dan juga desa adat. Apabila dicermati penyeragaman istilah ini sebenarnya dapat menimbulkan ambiguitas, sebab antara desa dengan desa adat masih mempunyai ciri yang berbeda, misalnya pemimpin desanya. Selain itu penyeragaman istilah ini juga sebenarnya dapat menghilangkan ciri atau karakter dari desadesa tersebut. Namun terlepas dari peristilahan tersebut, desa tetap mempunyai otonomi yang harus dilaksanakan sesuai dengan hukum yang berlaku.

Otonomi desa ini merupakan suatu konsep yang lahir atas prakarsa desa, bukan merupakan pemberian dari negara (pemerintah). Otonomi desa bahkan menjadi ide dasar dalam membentuk Negara

${ }^{2}$ C.F. Strong, Modern Political Constitution, An Introduction to the Comparative Study of Their History and Existing Form, Sidgwick \& Jackson Limited, London, 1966, h. 11.
Indonesia dan juga pelaksaan desentralisasi. Otonomi desa tidak boleh dipahami sebagai turunan atau cabang dari otonomi daerah. ${ }^{3}$ Pengakuan atas otonomi desa menurut Bagir Manan, ${ }^{4}$ terdapat dua hal yang harus diperhatikan. Pertama, pemerintahan desa tidak harus selalu menggunakan nama desa. Diperbolehkan menggunakan nama sesuai karakter adat istiadat desa, seperti dusun, marga, nagari, meunasah, gampong, dan sebagainya. Kedua, pengakuan atas otonomi asli.

Keberadaan desa sebagai suatu pemerintahan, seharusnya mampu dimanfaatkan oleh pemerintah untuk dapat meningkatkan pertumbuhan nasional, baik di bidang ekonomi, sosial, budaya maupun politik. Hal ini mengingat bahwa secara historis, desa mempunyai kemampuan untuk mandiri dalam melakukan pengelolaan desa. Apalagi setiap desa mempunyai potensi yang khas, baik potensi sumber daya alam maupun sumber daya manusia. Nilainilai yang hidup di masyarakat desa juga mampu membawa desa sebagai suatu komunitas yang maju. Tentunya untuk meciptakan kondisi yang demikian itu, perlu adanya pembinaan dari berbagai elemen, misalnya melalui Pemerintah Daerah Kabupaten/ Kota.

Problematika yang terjadi adalah justru pengakuan tentang otonomi desa ini masih belum secara utuh diberikan, artinya pemerintah masih raguragu untuk dapat memaksimalkan otonomi desa. Hal ini dapat dilihat dari pengaturan dalam UU No. 6 Tahun 2014, misalnya pada Pasal 90. Desa dapat melakukan pengelolaan terhadap sumber daya alam desa, tapi ternyata justru kewenangan pengelolaan sumber daya alam ini banyak dibebankan kepada pemerintah daerah melalui peraturan yang lain. Seolah-olah desa diberikan kewenangan, tapi justru dibatasi dengan adanya peraturan yang lainnya. Akibatnya desa tidak mampu untuk berkembang secara mandiri.

Telah dirumuskan pula bahwa setiap desa mempunyai Badan Usaha Milik Desa (BUMDesa) yang dibentuk dan dikelola oleh desa. Namun faktanya masih banyak BUMDesa yang belum diberdayakan secara maksimal. Hal ini disebabkan

3 Ateng Syafrudin dan Suprin Na'a, Republik Desa Pergulatan Hukum Tradisional dan Hukum Modern Dalam Desain Otonomi Desa, Alumni, Bandung, 2010, h. 10-12.

${ }^{4}$ Bagir Manan, Menyongsong Fajar Otonomi Daerah, Pusat Studi Hukum (PSH) FH-UII, Yogyakarta, 2001, h. 161-162. 
masyarakat maupun aparatur desa yang belum memahami secara tepat terkait dengan BUMDesa. Tindak lanjut dari Pemerintah Pusat ataupun Pemerintah Daerah untuk melakukan pembinaan terhadap BUMDesa ini juga masih belum dilakukan secara berkelanjutan. Akibatnya BUMDesa ini justru seolah mati, tidak mampu berkembang. Padahal jika BUMDesa ini dikembangkan secara benar dan tepat, maka dapat mengangkat pertumbuhan ekonomi desa, yang juga secara langsung berdampak pada pertumbuhan ekonomi nasional. Apalagi pada Pasal 90 huruf c UU No. 6 Tahun 2014, ditegaskan bahwa BUMDesa menjadi prioritas dalam melakukan pengelolaan sumber daya alam desa. Pemerintah maupun Pemerintah Daerah mempunyai kewajiban untuk memberikan dukungan dalam pengembangan BUMDesa ini, baik dukungan dalam bentuk materiil, maupun pembinaan.

Peraturan ataupun kebijakan yang dibentuk di tingkat pusat maupun daerah provinsi dan kabupaten/ kota, sering kali masih berbenturan dengan hukum adat yang berlaku di desa-desa. Sebagai contohnya ketika dalam Undang-Undang Nomor 41 Tahun 1999 tentang Kehutanan (yang selanjutnya disingkat UU No. 41 Tahun 1999), menegaskan pada Pasal 5 bahwa hutan adat termasuk bagian dari hutan negara. Ketentuan ini justru memberikan celah untuk menjual hutan dengan atas nama negara kepada pihak pemodal untuk mengeksploitasi hutan. Padahal ini justru bertentangan dengan hukum adat maupun kearifan lokal yang berlaku. Sering kali jika dihadapkan pada kondisi demikian itu, hukum adat menjadi tersisihkan. Akibatnya hak masyarakat desa adat menjadi dilanggar dan dirugikan. ${ }^{5}$

Semua persoalan tersebut semakin menunjukkan jika pemerintah masih belum serius dalam memberdayakan desa. Padahal melalui otonomi desa yang diberdayakan secara maksimal, maka dapat memberikan pertumbuhan ekonomi yang signifikan bagi negara. Apalagi dengan mengingat besarnya potensi yang dimiliki desa. Oleh karena itu pada penulisan ini berfokus pada optimalisasi pembangunan ekonomi nasional melalui otonomi

${ }^{5}$ Agus Sahbani, "MK Tegaskan Hutan Adat Bukan Milik Negara", 2013, <http://www.hukumonline.com/berita/baca/ lt5194c9568b9f7/mk-tegaskan-hutan-adat-bukan-milik-negara>, [05/01/2017]. desa, dengan didasarkan pada hukum serta konsep yang ada.

\section{PERUMUSAN MASALAH}

Bagaimana integrasi antara hukum modern negara dengan hukum yang hidup di desa, dalam kaitannya dengan pembangunan ekonomi nasional, serta bagaimana cara mengoptimalkan pembangunan ekonomi nasional melalui otonomi desa.

\section{METODE PENELITIAN}

Tipe penelitian dalam penulisan ini adalah penelitian normatif. Pendekatan yang digunakan dalam penelitian hukum adalah pendekatan undangundang atau statute approach. Dalam metode pendekatan perundang-undangan maka yang harus dipahami adalah hierarki, dan asas-asas dalam peraturan perundang-undangan

\section{PEMBAHASAN \\ Hakekat Otonomi Desa}

Secara etimologis istilah Desa berasal dari kata swadesi (dalam bahasa Sansekerta) yang artinya wilayah, tempat atau bagian yang mandiri dan otonom. ${ }^{6}$ Desa juga dipandang sebagai sekumpulan masyarakat yang bertempat di suatu wilayah dengan batas-batas tertentu. Antara individu masyarakat mempunyai keterikatan sosial yang sangat kuat. Nilai gotong royong dan musyawarah menjadi ciri khas masyarakat desa. ${ }^{7}$ Bahkan kearifan lokal di desa juga sangat terjaga.

Oleh Mashuri Maschab, ${ }^{8}$ setidaknya terdapat tiga sudut pandang tentang desa. Pertama, secara sosiologis di mana desa digambarkan sebagai komunitas penduduk yang tinggal menetap dalam suatu lingkungan dengan corak hidup homogen. Kedua, secara ekonomi bahwa desa sebagai suatu lingkungan masyarakat yang berusaha memenuhi kebutuhan hidupnya sehari-hari dari apa yang disediakan alam di sekitarnya. Ketiga, secara politk

${ }^{6}$ P.J. Zoetmulder bekerja sama dengan S.O. Robson, Kamus Jawa Kuno Indonesia, Gramedia Pustaka Utama, Jakarta, 2006, h. 212, yang telah dikutip oleh Ateng Syafrudin dan Suprin Na'a, Republik Desa, Op.Cit., h. 2.

${ }^{7}$ Soerjono Soekanto, Sosiologi Suatu Pengantar, Rajawali Pers, Jakarta, 2010, h. 55.

${ }^{8}$ Mashuri Maschab, Politik Pemerintahan Desa di Indonesia, POLGOV (Research Centre For Politics and Government, Department of Politics and Government), FISIPOL UGM, Yogyakarta, 2013, h. 1-3. 
yaitu sebagai suatu organisasi pemerintahan atau kekuasaan yang mempunyai wewenang karena merupakan bagian dari negara.

Berdasarkan pengertian tersebut, dapat disimpulkan bahwa pada hakikatnya desa merupakan bentuk pemerintahan riil, demokratis dan otonom, memiliki tradisi dan hukum atas prakasa sendiri serta sumber bagi terbentuknya kekuasaan yang lebih tinggi (negara). Oleh karena itu negara wajib mengakui dan menghormati entitas pemerintahan desa.

Otonomi desa merupakan otonomi yang asli, bulat, dan utuh serta bukan merupakan pemberian dari pemerintah. ${ }^{9}$ Keberadaan otonomi desa merupakan inti dari konsep Negara Kesatuan Republik Indonesia (selanjutnya disebut NKRI). Hal ini mengingat pula bahwa desa lahir sebelum adanya NKRI yang berdaulat. ${ }^{10}$ Adanya otonomi desa yang semacam itu, bukan berarti desa lepas dari hubungan antara pemerintah pusat dan pemerintah daerah. Desa tetap berhubungan dengan masing-masing pemerintahan yang kedudukannya lebih tinggi dari pada desa, baik dalam menjalankan kewenangan maupun tugas pembantuan. Hal ini dimaksudkan sebagai wujud koordinasi pemerintahan, guna mewujudkan tata pemerintahan yang lebih tertata.

Otonomi desa mengenal adanya hak asal usul, yang sekaligus menjadi sumber kewenangan desa. Hak asal usul ini merupakan karakter khas yang dimiliki desa, dan menjadi salah satu unsur yang membedakan dengan otonomi daerah. Hak asal usul ini merupakan bentuk pengakuan pemerintah kepada desa untuk dapat menggali dan mempertahankan kewenangan yang ada pada desa, dengan melihat pada perspektif historis desanya. Hak asal usul ini juga sekaligus menjadi identitas tradional desa dan menjadi bagian lex naturalis. ${ }^{11}$ Keberadaan living law di desa juga turut menjadi bagian dari hak asal usul yang dijamin oleh negara. Bahkan sebagian dari living law tersebut di adopsi dalam hukum positif untuk memperkuat eksistensi desa.

Konsekuensi atas diakuinya otonomi desa ini, maka kepentingan yang melekat pada desa tidak

${ }^{9}$ HAW. Widjaja, Otonomi Desa Merupakan Otonomi yang Asli, Bulat dan Utuh, Rajawali Pers, Jakarta, 2008, h. 165.

10 Ateng Syafrudin dan Suprin Na'a, Republik Desa... Op.Cit., h. 11.

${ }^{11}$ Ibid., h. 45. dapat secara serta merta dikesampingkan. Apalagi jika terkait dengan hukum. Hukum yang hidup di masyarakat desa, tidak dapat secara langsung dikesampingkan oleh hukum negara.

\section{Hubungan Otonomi Desa dan Pembangunan Ekonomi Nasional}

Otonomi desa memberikan keleluasaan kepada desa untuk dapat mengatur dan mengurus urusan rumah tangga desanya sesuai dengan hukum yang berlaku. Hal ini dimaksudkan agar desa mampu berkembang secara mandiri di berbagai sektor, khususnya bidang ekonomi. Desa dengan adanya otonomi dapat menjadi salah satu motor dan pilar dalam pembangunan ekonomi nasional. Secara statistik, jumlah desa di Indonesia tahun 2016 mencapai 81.253. ${ }^{12}$ Jumlah sebanyak itu tentunya akan sangat berperan penting dalam pembangunan ekonomi nasional.

Agenda pembangunan nasional yang dituangkan dalam Rencana Pembangunan Jangka Panjang Nasional (yang selanjutnya disingkat RPJPN) dan Rencana Pembangunan Jangka Menengah Nasional (yang selanjutnya disingkat RPJMN), telah memberikan ruang untuk menjadikan desa sebagai bagian prioritas dalam pembangunan ekonomi nasional. Tentu ini juga menjadi bukti bahwa membangun ekonomi dari sektor pemerintahan terendah, lebih memberikan nilai efektifitas yang tinggi.

Otonomi desa sebagai salah satu motor penggerak dan pilar dalam pembangunan ekonomi nasional, perlu mendapatkan dukungan. Dukungan ini diberikan oleh pemerintah, baik pusat maupun daerah. Salah satu bentuk dukungan adalah dengan memberikan legitimasi kepada desa untuk dapat berkembang secara mandiri. Pasal 19 UU No. 6 Tahun 2014 yang berkaitan dengan kewenangan desa juga merupakan bentuk dukungan dari pemerintah. Termasuk ketika dibentuk Peraturan Menteri yang mengatur mengenai berbagai hal teknis dalam penyelenggaraan pemerintahan desa. Memberikan legitimasi yang jelas kepada desa ini menjadi suatu bagian yang penting, sebab Indonesia adalah negara hukum, sehingga segala hal yang berkaitan dengan penyelenggaraan pemerintahan wajib mempunyai dasar hukum yang jelas. Hal ini juga dimaksudkan

\footnotetext{
${ }^{12}$ Data diperoleh dari www.bps.go.id.
} 
untuk menghindari terjadinya abuse of power dari penguasa.

Hubungan antara otonomi desa dengan pembangunan ekonomi nasional bersifat berkelanjutan, artinya peran otonomi desa ini tidak hanya berhenti ataupun terbatas pada waktu tertentu. Melalui adanya otonomi desa ini tentu sangat berperan dalam pembangunan ekonomi. Desa dapat memberdayakan masyarakatnya dalam mengembangkan potensi desa, misalnya dengan membentuk kegiatan usaha melalui BUMDesa. Kegiatan tersebut juga akan menjadi sejalan dengan visi Indonesia dalam menciptakan kesejahteraan umum.

\section{Integrasi Hukum Modern Negara dengan Hukum yang Hidup di Desa dalam Konteks Pembangunan Ekonomi Nasional}

Hukum merupakan sarana untuk menciptakan ketertiban di masyarakat. Roscoe Pound ${ }^{13}$ berpendapat bahwa the first and simplest idea is that law exist in order to keep the peace in a given society, to keep the peace at all events and at any price. Apabila hukum telah mampu untuk menciptakan kondisi yang aman di masyarakat, maka segala aspek kehidupan di masyarakat juga akan menjadi lebih tertata. Meminimalisir terjadinya konflik di masyarakat.

Apabila ditelaah lebih lanjut dari sudut pandang fungsi hukum, setidaknya terdapat empat fungsi dasar, yaitu Hukum sebagai: pemelihara ketertiban dan keamanan; sarana pembangunan; sarana penegak keadilan; sarana pendidikan di masyarakat. ${ }^{14}$

Keempat fungsi tersebut juga sekaligus menjadi pedoman dalam pembentukkan hukum. Pada proses pembentukkan hukum, haruslah dapat dipastikan bahwa hukum yang dibentuk mampu untuk menjalankan fungsinya secara tepat. Pembangunan ekonomi tidak dapat dipisahkan dari pembangunan hukum, karena antara ekonomi dan hukum itu merupakan dua hal yang saling mempengaruhi satu sama lain. ${ }^{15}$

\footnotetext{
${ }^{13}$ Roscoe Pound, An Introduction To The Philosophy of Law, Yale University Press, New Haven, 1961, h. 33.

14 Sunaryati Hartono, Hukum Ekonomi Pembangunan Indonesia, Binacipta, Bandung, 1988, h. 10.

${ }^{15}$ Dewa Ayu Made Kresna Puspita Santi dan I Gusti Ngurah Parwata, "Fungsi Hukum Dalam Pembangunan Ekonomi", Artikel Tidak Dipublikasikan, 2013, h. 2.
}

Pada era Orde Baru, para pakar ekonomi, pelaku ekonomi, dan penguasa memandang hukum sebagai penghambat bagi terselenggaranya kegiatan ekonomi. Pada waktu itu hukum tidak dijadikan sebagai landasan, pemandu dan penegak aktivitas dalam bidang ekonomi. Keberadaan hukum di rusak oleh penguasa, hanya untuk membela kepentingan politik ekonomi orde baru yang mengabdi pada kepentingan negara-negara maju. Akibatnya hukum lebih banyak bergerak statis, dan seolah tidak mampu menyesuaikan dengan perkembangan. Seiring dengan berjalannya waktu, perlahan kewibawaan hukum mulai dipandang untuk menciptakan iklim ekonomi yang kondusif dan untuk menarik investasi. Hal ini juga yang menggiring perkembangan hukum di Indonesia, menjadi hukum modern. ${ }^{16}$

Terdapat tiga karakteristik dasar mengenai hukum modern, antara lain: Bersifat sekuler dan progmatis; Berorientasi kepada kepentingan dan merupakan usaha yang dilakukan secara sadar oleh manusia; dan Bersifat terbuka dan mengandung unsur perubahan yang dilakukan secara sengaja. ${ }^{17}$

Dipahami lebih lanjut bahwa hukum modern lebih berbentuk tertulis. Pembentukannya dinilai lebih rasional dengan mengedepankan kemanfaatan. Lebih terstruktur (hirarkis), sehingga pelaksanaan jelas dan terarah. ${ }^{18}$ Namun hukum modern yang pembangunan ekonomi, lebih banyak berorientasi pada kepentingan kapital. Akibatnya hukum yang hidup di lingkungan masyarakat desa atau living law, justru menjadi tertindas. Padahal seharusnya dengan adanya hukum modern ini mampu untuk mengakomodir segala kepentingan, termasuk ketika dihadapkan pada living law.

Apabila melihat pada konsep unifikasi hukum Indonesia, living law atau yang juga dikenal sebagai hukum adat, menjadi salah satu unsur hukum nasional. Jelas ini memberikan suatu konsekuensi bahwa pemerintah tidak boleh secara sepihak mengabaikan keberadaan living law. ${ }^{19}$ Membangun hukum ekonomi tidak hanya berbicara kepentingan

${ }^{16}$ Adi Sulistiyono dan Muhammad Rustamaji, Hukum Ekonomi Sebagai Panglima, Masmedia Buana Pustaka, Surabaya, 2009, h. 16.

${ }^{17}$ Ronny Hanitijo Soemitro, Masalah-Masalah Sosiologi Hukum, Sinar Baru, Bandung, 1984, h. 82-83.

${ }^{18}$ Ibid., h. 55.

${ }^{19}$ Sunaryati Hartono, Politik Hukum Menuju Satu Sistem Hukum Ekonomi Nasional, Alumni, Bandung, 1991, h. 61-65. 
secara umum, tapi juga perlu mempertimbangkan hak-hak tradisional masyarakat. Apalagi secara konstitusional negara mempunyai kewajiban untuk menghormati hak-hak tradisional masyarakat.

Living law merupakan bagian dari masyarakat desa sebagai satu kesatuan yang bersifat otonom, mengatur sistem kehidupan sendiri, yang lahir dari dan dalam masyarakat itu sendiri dan dijaga oleh masyarakatnya. Penjelasan Bab IV UndangUndang Dasar Sebelum Amandemen tersirat di dalamnya bahwa di Indonesia terdapat kurang lebih 250 zelfbestuurende land scappen dan volksgemenscappen yang mempunyai sistem sosial sendiri dan mempunyai hubungan yang kuat dengan tanah, pengelolaan sumber daya alam, dan kekuasaan mempertahankan nilai-nilai setempat atau kearifankearifan lokal. ${ }^{20}$ Melalui living law ini sebenarnya telah memberikan keleluasaan kepada desa untuk dapat berkembang secara mandiri.

Ada empat karakteristik dasar yang dimiliki oleh living law, antara lain mempunyai: ${ }^{21}$ Mempunyai sifat kolektivisme yang kuat, dan Corak magisreligius yang berhubungan dengan pandangan hidup masyarakat asli; Diliputi oleh pikiran yang kongkrit, sangat memperhatikan banyaknya dan berulangnya hubungan kongkrit yang terjadi; serta Bersifat visual, artinya hubungan hukum dianggap terjadi hanya jika ditetapkan dengan suatu ikatan yang dapat dilihat atau dengan tanda yang tampak.

Living Law mengalami gonjangan yang begitu besar di era globalisasi saat ini. Goncangan tersebut dikarenakan terjadi perubahan-perubahan sosial di dalam masyarakat yang meliputi pelbagai aspek kehidupan, termasuk ekonomi. Intimidasi dari hukum modern yang kurang berpihak pada kepentingan dan keberadaan living law, menjadikan eksistensi semakin tergerus. ${ }^{22}$ Sebagai contohnya adalah ketika hutan adat justru dikuasai oleh pemerintah berdasarkan UU No. 41 Tahun 1999, dan dijual kepada kaum kapital, hak tradisional masyarakat desa menjadi tersingkir. Kondisi ini pun semakin diperparah dengan tidak dilibatkannya masyarakat desa dalam melakukan pemanfaatan lahan hutan tersebut. Bahkan

\footnotetext{
${ }^{20}$ Herman dan Manan Sailan, Pengantar Hukum Indonesia, Badan Penerbit UNM, Makassar, 2012, h. 60.

${ }^{21}$ Ronny Hanitijo Soemitro, Masalah...., Op.Cit., h. 54.

22 Satjipto Rahardjo, Wajah Hukum di Era Reformasi: (Kumpulan Karya Ilmiah Menyambut 70 Tahun Prof. Dr. Satjipto Rahardjo, S.H., Citra Aditya Bakti, Bandung, 2010, h. 51.
}

kaum pemodal yang telah menguasai lahan hutan, justru melakukan eksploitasi besar-besaran dan mengabaikan nilai-nilai kearifan lokal yang hidup di masyarakat sekitar. ${ }^{23}$ Akibatnya pertumbuhan ekonomi masyarakat desa menjadi mati. Lahan yang seharusnya dapat dimanfaatkan untuk kepentingan mereka justru direnggut. Disinilah posisi hukum modern negara yang justru bertindak otoriter terhadap living law.

Kondisi demikian itu tidak perlu terjadi jika dalam pembentukan hukum atau law making process negara memperhatikan pula pada fungsi hukum itu sendiri. Selain itu ada tiga aspek atau geldingsgrondslag van strafrecht mendasar yang juga harus diperhatikan dalam pembentukan hukum, yaitu: Memenuhi aspek filosofis, yaitu hukum yang dianggap memenuhi rasa keadilan (filosofische geldingsgrondslag); Memenuhi aspek sosiologis, bahwa hukum yang dibentuk dapat diterima masyarakat (sociologische geldingsgrondslag); Aspek yuridis (juridische geldingsgrondslag), yaitu bahwa hukum tersebut merupakan hasil dari perumusan oleh badan yang berwenang, dan tidak bertentangan dengan hukum yang lebih tinggi. ${ }^{24}$

Ketiga aspek tersebut haruslah dipenuhi secara kumulatif, sebab jika ada salah satu aspek yang kurang, maka dapat mempengaruhi validitas hukum tersebut. Sering kali dalam pembentukan hukum aspek-aspek tersebut tidak diperhatikan secara tepat. Kajian yang dilakukan melalui pembentukan naskah akademik, masih belum mampu dilaksanakan secara utuh. Padahal apabila melihat pada UndangUndang Nomor 12 Tahun 2011 tentang Pembentukan Peraturan Perundang-undangan (UU No. 12 Tahun 2011), ditegaskan perlunya untuk membentuk naskah akademik sebelum membentuk peraturan perundangundangan. Tentunya dengan berpegang pada tiga aspek dasar tersebut, dapat menggali tentang hukum yang hidup di masyarakat.

Perlulah untuk kembali merefleksi, bahwa dalam integrasi hukum dalam pembangunan ekonomi ini,

${ }^{23}$ Muhammad Agung Riyadi, "Hutan Adat Bukan Hutan Negara, AMAN Desak Pemerintah Laksanakan MK35", <http:// www.gresnews.com/berita/hukum/211163-hutan-adat-bukanhutan-negara-aman-desak-pemerintah-laksanakan-mk35/0/>, [05/01/2017].

24 T. Boestomi, Hukum Perdata dan Hukum Tata Usaha Negara Dalam Teori dan Praktek, Alumni, Bandung, 1994, h. 56-57. 
harus kembali mengingat dan mendasarkan pada Pancasila sesuai dengan Pasal 2 UU No. 12 Tahun 2011. Hal ini mengingat bahwa Pancasila adalah transformasi dari seluruh kaidah hukum yang ada di Indonesia. Memahami Pancasila haruslah secara menyeluruh. Pertama, dengan berdasarkan pada sila kesatu, hukum yang dibentuk haruslah mampu menghargai dan mengakomodir nilai-nilai spiritual yang hidup di lingkungan masyarakat desa. Hal ini menjadi penting mengingat living law mempunyai karakter yang religius. Karakter tersebut juga memberikan suatu dampak yang positif dalam pelaksanaan hukum di lingkungan masyarakat desa. Hukum negara melalui peraturan perundangundangan, haruslah mampu mengakomodir kepentingan ini.

Kedua, berdasarkan sila kedua bahwa terdapat suatu hak-hak tradisional masyarakat desa yang harus dilindungi. Hal ini sangat erat kaitannya dengan kemanusiaan. Hak tradisional masyarakat desa merupakan lex naturalis yang tidak dapat dipisahkan dari eksistensi desa. Jika hukum modern negara justru mengabaikan hak-hak ini, maka hukum tersebut dapat dikategorikan telah melanggar hak asasi manusia. Apalagi jika mengingat bahwa hak tradisional bukan merupakan pemberian negara, melahirkan lahir dari kehidupan masyarakat desa, bahkan jauh sebelum negara terbentuk.

Ketiga, berdasarkan sila ketiga perlunya untuk menjaga persatuan melalui keseimbangan kepentingan. Suatu negara pasti terdiri dari berbagai macam kepentingan, tapi negara juga harus mampu untuk menyeimbangkan berbagai kepentingan tersebut. Berkaitan dengan pembangunan ekonomi ini, di satu sisi negara dihadapkan dengan kepentingan pemodal yang ingin melakukan okupasi terhadap sumber daya yang ada di wilayah Indonesia. Di sisi lain, negara juga dihadapkan dengan keberadaan masyarakat desa dengan otonomi desanya. Jalan tengah yang dapat diambil adalah, pemerintah membentuk suatu kebijakan dengan memberdayakan masyarakat desa dengan memanfaatkan pemodal. Hak atas lahan tidak boleh beralih kepada pemodal. Pada posisi ini memang perlu ketegasan dari pemerintah melalui legal policy yang dibentuk, sebab hal tersebut menjadi suatu legitimasi dalam melaksanakan pembangunan ekonomi berbasis otonomi desa.
Jangan sampai persatuan negara menjadi pecah hanya karena mementingkan kepentingan kapitalis.

Keempat, sesuai dengan sila keempat, maka perlu mengajak masyarakat desa untuk berdialog dalam pembentukan hukum. Pemerintah diharuskan untuk turun menemui warga masyarakatnya dan melakukan musyawarah untuk mencapai permufakatan dengan masyarakat desa secara langsung. Hal ini menjadi penting, mengingat sering kali dalam setiap pembentukan peraturan perundang-undangan maupun kebijakan, pemerintah kurang mengajak masyarakatnya untuk berdialog. Padahal melalui dialog dalam forum musyarawarat, dapat diketahui secara jelas kepentingan masyarakat desa tersebut, khususnya untuk mempelajari dan mengetahui hukum yang hidup di desa.

Kelima, berdasarkan sila kelima, ibarat sebuah mata air. Segala sesuatu yang dilakukan haruslah memunculkan nilai keadilan sosial. Tentunya keadilan sosial ini adalah keadilan bidang ekonomi bagi masyarakat. Masyarakat desa mendapatkan haknya untuk menerima manfaat dari apa yang mereka lakukan. Bagaimanapun juga, kesejahteraan rakyat menjadi subyek yang harus diutamakan oleh pemerintah.

Apabila semua uraian tersebut mampu untuk diaktualisasikan, maka integrasi antara hukum modern negara dengan hukum yang hidup di masyarakat, akan terwujud secara benar. Konflik norma antara hukum negara dengan living law juga akan terhindarkan. Kekuasaan yang melekat pada negara, haruslah mampu diterapkan secara tepat agar menciptakan keseimbangan dari berbagai pemangku kepentingan.

\section{Otonomi Desa Sebagai Pijakan Dalam Mengoptimalkan Pembangunan Ekonomi Nasional}

Saat ini pemerintah sedang gencar untuk memprioritaskan pelaksanaan otonomi desa. Pemerintah berusaha untuk mengembangkan desa sebagai poros ekonomi nasional. Hal ini dilakukan mengingat potensi desa yang begitu besar. Jumlah desa yang begitu banyak, dan ciri khas potensi desa, menjadikan desa dinilai mampu untuk menjadi penyokong pembangunan ekonomi nasional.

Ditinjau secara historis, program untuk mengembangkan desa sebenarnya telah dimulai 
sejak awal kemerdekaan Indonesia. Pemerintah pada masa itu menyusun peraturan yang dijadikan sebagai landasan bagi desa untuk dapat menjalankan pemerintahan secara otonom, yaitu Undang-Undang Nomor 22 Tahun 1948 tentang Penetapan AturanAturan Pokok Mengenai Pemerintahan Sendiri di Daerah-Daerah yang Berhak Mengatur dan Mengurus Rumah Tangganya Sendiri (UU No. 22 Tahun 1948). Ketidakstabilan kondisi negara pada masa itu, mengakibatkan aturan tersebut tidak dilaksanakan secara utuh. Seiring dengan perkembangan rezim yang terjadi, kebijakan untuk mengembangkan desa masih tetap dilakukan. Hanya saja belum menjadi agenda prioritas, sebab pemerintahan Indonesia sebelum era reformasi masih lebih berfokus pada pembangunan sentralistik. ${ }^{25}$

Gagasan tentang pembangunan ekonomi nasional melalui desa ini juga pernah ditegaskan oleh Hatta. Demokrasi ekonomi suatu negara hendaknya juga dilaksanakan sampai pada lingkungan pemerintahan desa. Hal ini akan memberikan dampak yang signifikan terhadap pertumbuhan ekonomi nasional. Desa mempunyai karakteristik otonomi yang khas. Namun untuk dapat mencapai tujuan tersebt diperlukan adanya pembinaan dari pemerintahan kabupaten/kota, hingga akhirnya desa benar-benar mampu melaksanakan otonominya secara utuh. ${ }^{26}$

Otonomi pada dasarnya mengandung arti kemandirian untuk mengatur dan mengurus urusan (rumah tangganya) sendiri. ${ }^{27}$ D.O. Adeyemo berpendapat, bahwa Local Government autonomy is perceived as local self government or grassroots democracy. This grassroots democracy is primarily aimed at giving the vast majority of the people the fullest opportunity to participate in determining their own destiny. But it is obvious that we cannot have complete autonomy or complete local self-government within sovereign states. If local governments were completely autonomous they would be sovereign states. ${ }^{28}$

\footnotetext{
${ }^{25}$ Hanif Nurcholis, Pertumbuhan dan Penyelenggaraan Pemerintahan Desa, Erlangga, Jakarta, 2011, h. 215.

26 Muhammad Hatta, Kedaulatan Rakyat, Otonomi \& Demokrasi, Kreasi Wacana, Bantul, 2014, h. 21-23 dan 72.

27 Bagir Manan, Hubungan Antara Pusat dan Daerah Menurut UUD 1945, Pustaka Sinar Harapan, Jakarta, 1994, h. 21.

28 D.O. Adeyemo, "Local Government Autonomy in Nigeria: A Historical Perspective", 10: 2 Journal Social Science, 2005, h. 79.
}

Berdasarkan definisi tersebut dapat dipahami bahwa pada prinsipnya otonomi merupakan bentuk kebebasan bagi daerah untuk mengatur urusan pemerintahan, tapi bukan dalam arti sebebasbebasnya. Inilah juga yang memunculkan perlunya koordinasi antar pemerintahan. Otonomi juga sekaligus menjadi akar demokrasi, maka pantaslah jika pelaksanaan demokrasi ekonomi juga harus turun sampai pada pemerintahan desa. Sejalan dengan pemahaman tersebut, maka lebih lanjut pandangan otonomi menurut Emezi, ${ }^{29}$ bahwa System of local administration under local communities that are organized to maintain law and order, provide some limited range of social amenities, and encourage cooperation and participation of inhabitants towards the improvement of their conditions of living. It provides the community with formal organizational framework which enables them to conduct their affairs effectively for the general good.

Adanya otonomi ini akan mendorong bagi tiap-tiap desa dalam meningkatkan pertumbuhan ekonomi. Meningkatkan partisipasi masyarakat dalam membangun sektor usaha yang difasilitasi oleh pemerintah desa. Tentu ini akan sangat berdampak pada tingkat kesejahteraan masyarakatnya. Bagaimana pun juga tingkat kesejahteraan masyarakat juga sangat dipengaruhi oleh kondisi ekonominya.

Memaknai pembangunan ekonomi melalui otonomi desa, juga harus diikuti dengan pembangunan kualitas sumber daya manusianya. Justru pembangunan kualitas sumber daya manusia ini merupakan kunci utama dalam kemajuan ekonomi. Tanpa adanya kualitas sumber daya manusia yang mumpuni, akan menjadi sulit untuk membangun ekonomi. Pemberdayaan masyarakat haruslah terus dilakukan secara berkelanjutan. Melalui adanya pendampingan yang dilakukan oleh pemerintah kabupaten/kota beserta pemerintah desa, terus memberikan bentuk-bentuk pelatihan kepada masyarakat, seperti soft skill, ataupun trik pengembangan usaha.

Paradigma klasik yang masih sering melekat pada masyarakat desa adalah keinginan untuk melakukan urbanisasi. Mereka mengadu nasib di kota-kota besar dengan kemampuan terbatas. Mereka berpandangan

${ }^{29}$ Emezi Cleus 1984. "Local Government in Historical Perspective", 2:2 Nigerian Journal of Public Administration and Local Government, 1984, h. 51. 
bahwa di desa tidak ada lagi yang dapat dikerjakan, kendati pun ada tidak mampu memberikan hasil yang lebih kepada mereka. ${ }^{30}$ Paradigma demikian inilah yang harus dirubah, melalui pemberdayaan dan pelatihan masyarakat. Memberikan edukasi baik teori maupun praktek untuk dapat mengembangkan kemampuan pribadi.

Arthur Dunham ${ }^{31}$ merumuskan pembangunan masyarakat desa sebagai organized efforts to improve the conditions of community life, primarily through the enlistment of self-help and cooperative effort from the villagers, but with technical assistance from government or voluntary organization. Berdasarkan uraian tersebut dapat diketahui ciri pembangunan masyarakat desa yaitu: pertama, adanya usahausaha yang terorganisir untuk memperbaiki kondisi kehidupan masyarakat; kedua, adanya peningkatan usaha kerjasama dan gotong royong dalam melaksanakan pembangunan; ketiga, pembangunan masyarakat desa memerlukan bantuan teknis dari pemerintah dan organisasi sukarela.

Lebih lanjut Arthur Dunham ${ }^{32}$ mengemukakan empat unsur pembangunan masyarakat desa yaitu: 1. a plan program with a focus on the total needs of the village community; 2. technical assistance; 3. integrating various specialties for the help of the commnunity; and 4. a major emphasis upon self-help and participation by the residents of the community. Keempat unsur tersebut menekankan pembangunan masyarakat desa adalah suatu program yang terencana, berfokus pada kebutuhan masyarakat, memerlukan bantuan teknis dari para ahli dari berbagai bidang, dan mengutamakan kegiatankegiatan gotong royong untuk menumbuhkan partisipasi aktif masyarakat dalam pembangunan. Hal tersebut tentunya sesuai dengan karakteristik masyarakat desa di Indonesia yaitu kekeluargaan dan gotong royong. Dengan demikian dalam rangka pembangunan sumber daya manusia perlu melibatkan berbagai unsur, baik pemerintah, akdemisi maupun praktisi.

Sebagaimana telah dirumuskan dalam UU No. 6 Tahun 2014, bahwa desa dapat membentuk

${ }^{30}$ Ali Hanapiah Muhi, Fenomena Pembangunan Desa, Institut Pemerintahan Dalam Negeri, Jatinangor, 2011, h. 9-10.

${ }^{31}$ Arthur Dunham, Community Welfare Organization, Princples and Practice, Thomas Y. Crowel Company, New York, 1958, h. 40-41.

${ }^{32}$ Ibid., h. 43-44.
BUMDesa yang dimaksudkan sebagai wadah dalam melakukan kegiatan usaha. Keberadaan BUMDesa ini sangatlah berperan dalam meningkatkan pertumbuhan ekonomi desa. Apalagi melalui BUMDesa dapat melakukan pengelolaan terhadap sumber daya alam ataupun potensi lain yang dimiliki desa, untuk dapat dimanfaatkan sebagai sumber perekonomian. Sesuai dengan tujuan pembentukan BUMDesa, antara lain: Mendorong perkembangan perekonomian desa; Meningkatkan pendapatan asli desa; Meningkatkan kreatifitas dan peluang usaha ekonomi produktif masyarakat desa yang berpenghasilan rendah; Mendorong berkembangan usaha mikro sektor informal.

Pelaksanaan BUMDesa ini masih belum opmitimal, dikarenakan beberapa aspek. Pertama, kurangnya dukungan dari pemerintah desa maupun pemerintah pusat dan daerah dalam memberdayakan BUMDesa. Walaupun pemerintah pusat memberikan bantuan dana kepada desa, tapi dana tersebut tidak dapat terserap secara maksimal untuk mengembangkan ekonomi desa. Perlu dilakukan pembinaan secara langsung dalam hal pelaksanaannya. Kedua, tingkat pemahaman aparatur desa tentang BUMDesa maupun peta potensi desa yang masih rendah. Walaupun telah dibentuk Peraturan Menteri Desa, Pembangunan Daerah Tertinggal, dan Transmigrasi Nomor 4 Tahun 2015 tentang Pendirian, Pengurusan dan Pengelolaan, dan Pembubaran Badan Usaha Milik Desa (Permendesa 4 Tahun 2015), tidak secara otomatis memberikan pemahaman yang utuh kepada masyarakat dan aparaturnya. Ketiga, tingkat partisipasi masyarakat yang masih kurang. Masyarakat enggan untuk berpartisipasi karena hasil nyata dari pelaksanaan BUMDesa ini belum terlihat. Di sisi lain masyarakat juga masih banyak yang belum memahami tentang tata cara teknis pelaksanaan BUMDesa ini. Keempat, kurangnya sarana dan prasana yang dimiliki di lingkungan desa.

Pada tahap pertama untuk dapat mengoptimalkan BUMDesa, perlu dilakukan pengkajian terhadap potensi yang dimiliki desa. Tentunya tidak setiap desa di Indonesia mempunyai potensi yang sama. Kendati pun desa tidak mempunyai potensi sama sekali, maka melalui kajian tersebut dapat memberikan suatu arahan untuk mengembangkan ekonomi desa. Selanjutnya memang diperlukan adanya penggerak 
dalam lingkungan desa. Di suatu desa pasti terdapat pemimpin formal dan informal. Pemimpin formal adalah mereka yang mengisi jabatan kepemimpinan seperti kepala desa, ketua suku, ataupun istilah lain, sedangkan pemimpin informal adalah mereka yang mempunyai kemauan dan kemampuan untuk menggerakan masyarakat (ketokohan).

Kepala desa atau pemimpin desa mempunyai peran dalam mengeluarkan peraturan atau kebijakan yang menjadi landasan hukum dalam mengembangkan ekonomi desa. Dasar hukum ini menjadi penting, sebab ini merupakan sarana untuk memberikan legitimasi yang jelas. Tanpa adanya dasar hukum ini, dapat berpotensi menimbulkan konflik. Peran tokoh masyarakat lebih banyak bersifat teknis, menjadi contoh dalam mengawali pembentukan BUMDesa. Kegiatan ini dilakukan setelah melakukan penataan pada sektor sumber daya manusianya. Pada posisi inilah juga diperlukan adanya bentuk koordinasi struktural pemerintahan, bahkan juga melibatkan sektor keuangan. Hal ini dimaksudkan agar tidak terjadi tindakan yang dapat merugikan keuangan desa.

Keterlibatan pemerintah desa sebagai pendiri BUMDesa bersama masyarakat diharapkan mampu memenuhi Standar Pelayanan Minimal (SPM). Pemerintah desa harus lebih berperan pada pembentukan dan pelaksanaan BUMDesa. Sebagai sebuah badan hukum, BUMDesa berpijak pada tata aturan perundang-undangan yang berlaku, serta sesuai dengan kesepakatan yang terbangun di masyarakat desa. Apabila BUMDesa ini mampu terselenggara secara baik dan berkelanjutan, maka bukan tidak mungkin akan terjadi pertumbuhan dratis perekonomian nasional.

\section{PENUTUP}

\section{Kesimpulan}

Pertama, Integrasi yang dapat dilakukan antara hukum modern negara dengan hukum yang hidup di masyarakat desa (living law) adalah dengan tidak selalu mengesampingkan keberadaan living law. Perlu kembali memperhatikan fungsi dasar hukum. Pada saat proses pembentukan hukum, kiranya aspek filosofis, sosiologis, dan yuridis, harusnya dikaji secara mendalam. Refleksi kembali atas pemahaman Pancasila juga sangat diperlukan. Hal ini mengingat bahwa Pancasila adalah hasil transformasi dari berbagai kaidah hukum yang ada di Indonesia.

Kedua, Optimalisasi dilakukan dengan melakukan perbaikan pada kualitas sumber daya manusianya. Tindakan tersebut adalah hal utama yang harus terlebih dahulu dilakukan. Diikuti dengan membangun Badan Usaha Milik Desa (BUMDesa), yang dibentuk dan dikelola oleh desa. Kemudian semua itu haruslah didasarkan pada hukum yang menjadi sebuah legitimasi dalam melaksanakan setiap tindakan. Pemerintah desa dapat membentuk peraturan desa yang mengikat dalam pelaksanaan pembangunan ekonomi desa.

\section{Rekomendasi}

Setelah melakukan analisa melalui penulisan ini, penulis dapat memberikan beberapa saran antara lain:

Pertama, Ketika peraturan perundang-undangan dihadapkan pada living law, maka peraturan tersebut tidak dapat secara serta merta berlaku superior dan meniadakan living law. Perlu untuk dilakukan pengkajian terlebih dahulu atas pelaksanaan peraturan perundang-undangan tersebut.

Kedua, Perlu kembali merefleksi Pancasila sebagai landasan fundamental dan sumber dari segala sumber dalam pembentukan peraturan perundangundangan Indonesia. Pemahaman tentang Pancasila ini haruslah secara utuh.

Ketiga, Eksistensi living law haruslah benarbenar dihormati dan menjadi landasan utuh dalam pelaksanaan otonomi desa.

Keempat, Pembangunan ekonomi di desa, haruslah dilakukan melalui strategi dan koordinasi yang tepat. Perlu untuk terlebih dulu melakukan pembenahan atas kualitas sumber daya manusianya. Bersamaan dengan itu, juga dilakukan pengkajian atas potensi yang dimiliki atau dapat dikembangkan di desa sebagai sumber ekonomi. Barulah melakukan penataan pada Badan Usaha Milik Desa. Semua hal tersebut dilakukan dengan keterlibatan pemerintah pusat, daerah, dan desa, masyarakat, akademisi, serta praktisi.

\section{DAFTAR PUSTAKA}

\section{Peraturan Perundang-undangan:}

Undang-Undang Dasar Negara Republik Indonesia Tahun 1945. 
Undang-Undang Nomor 22 Tahun 1948 tentang Penetapan Aturan-Aturan Pokok Mengenai Pemerintahan Sendiri di Daerah-Daerah yang Berhak Mengatur dan Mengurus Rumah Tangganya Sendiri.

Undang-Undang Nomor 12 Tahun 2011 tentang Pembentukan Peraturan Perundang-undangan.

Undang-Undang Nomor 6 Tahun 2014 tentang Desa. Peraturan Menteri Desa, Pembangunan Daerah Tertinggal, dan Transmigrasi Nomor 4 Tahun 2015 tentang Pendirian, Pengurusan dan Pengelolaan, dan Pembubaran Badan Usaha Milik Desa.

\section{Buku:}

Boestomi, T., 1994, Hukum Perdata dan Hukum Tata Usaha Negara Dalam Teori dan Praktek, Bandung: Alumni.

Dunham, Arthur, Community Welfare Organization, Princples and Practice, New York: Thomas Y. Crowel Company.

Hartono, Sunaryati, 1988, Hukum Ekonomi Pembangunan Indonesia, Bandung: Binacipta. , 1991, Politik Hukum Menuju Satu Sistem Hukum Ekonomi Nasional, Bandung: Alumni.

Hatta, Muhammad, 2014, Kedaulatan Rakyat, Otonomi \& Demokrasi, Bantul: Kreasi Wacana.

Herman dan Manan Sailan, 2012, Pengantar Hukum Indonesia, Makassar: Badan Penerbit UNM.

Manan, Bagir, 1994, Hubungan Antara Pusat dan Daerah Menurut UUD 1945, Jakarta: Pustaka Sinar Harapan. , 2001, Menyongsong Fajar Otonomi Daerah, Yogyakarta: Pusat Studi Hukum (PSH) FH-UII.

Maschab, Mashuri, 2013, Politik Pemerintahan Desa di Indonesia, Yogyakarta: PolGov, Research Centre For Politics and Government, Department of Politics and Government, FISIPOL UGM.

Muhi, Ali Hanapiah, 2011, Fenomena Pembangunan Desa, Jatinangor: Institut Pemerintahan Dalam Negeri.

Nurcholis, Hanif, 2011, Pertumbuhan dan Penyelenggaraan Pemerintahan Desa, Jakarta: Erlangga.

Pound, Roscoe, 1961, An Introduction to The Philosophy of Law, New Haven: Yale University Press.
Rahardjo, Satjipto, 2010, Wajah Hukum di Era Reformasi: (Kumpulan Karya Ilmiah Menyambut 70 Tahun Prof. Dr. Satjipto Rahardjo, S.H.), Bandung: Citra Aditya Bakti.

Soekanto, Soerjono, 2010, Sosiologi Suatu Pengantar, Jakarta: Rajawali Pers.

Soemitro, Ronny Hanitijo, 1984, Masalah-Masalah Sosiologi Hukum, Bandung: Sinar Baru.

Strong, C.F., 1966, Modern Political Constitution, An Introduction to the Comparative Study of Their History and Existing Form, London: Sidgwick \& Jackson Limited.

Sulistiyono, Adi dan Muhammad Rustamaji, 2009, Hukum Ekonomi Sebagai Panglima, Surabaya: Masmedia Buana Pustaka.

Syafrudin, Ateng dan Suprin Na'a, 2010, Republik Desa Pergulatan Hukum Tradisional dan Hukum Modern Dalam Desain Otonomi Desa, Bandung: Alumni.

Wheare, K.C., 1966, Modern Constitution, London: Oxford University Press.

Widjaja, HAW., 2008, Otonomi Desa Merupakan Otonomi yang Asli, Bulat dan Utuh, Jakarta: Rajawali Pers.

\section{Jurnal, Website, Artikel:}

Adeyemo, D.O., 2005, "Local Government Autonomy in Nigeria: A Historical Perspective", 10: 2 Journal Social Science.

Cleus, Emezi, 1984. "Local Government in Historical Perspective", 2: 2 Nigerian Journal of Public Administration and Local Government.

Dewa Ayu Made Kresna Puspita Santi dan I Gusti Ngurah Parwata, 2013, "Fungsi Hukum Dalam Pembangunan Ekonomi", Artikel Tidak Dipublikasikan.

Riyadi, Muhammad Agung, "Hutan Adat Bukan Hutan Negara, AMAN Desak Pemerintah Laksanakan MK35", <http://www.gresnews.com/ berita/hukum/211163-hutan-adat-bukan-hutannegara-aman-desak-pemerintah-laksanakan$m k 35 / 0 />,[05 / 01 / 2017]$.

Sahbani, Agus, "MK Tegaskan Hutan Adat Bukan Milik Negara", 2013, <http://www.hukumonline. com/berita/baca/lt5194c9568b9f7/mk-tegaskanhutan-adat-bukan-milik-negara $>$, [05/01/2017]. 